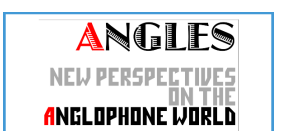

ANELOPHONE WORLI

\section{Angles}

New Perspectives on the Anglophone World

5 | 2017

The Cultures and Politics of Leisure

\title{
Video introduction to issue 5
}

\section{Laurent Châtel and Thibaut Clément}

\section{Q OpenEdition}

\section{Journals}

\section{Electronic version}

URL: https://journals.openedition.org/angles/1119

DOI: 10.4000/angles. 1119

ISSN: 2274-2042

\section{Publisher}

Société des Anglicistes de l'Enseignement Supérieur

\section{Electronic reference}

Laurent Châtel and Thibaut Clément, "Video introduction to issue 5", Angles [Online], 5 | 2017, Online since 01 November 2017, connection on 10 June 2022. URL: http://journals.openedition.org/angles/ 1119 ; DOI: https://doi.org/10.4000/angles. 1119

This text was automatically generated on 10 June 2022 .

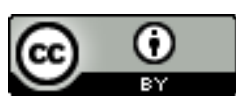

Angles est mise à disposition selon les termes de la Licence Creative Commons Attribution 4.0 International. 


\title{
Video introduction to issue 5
}

\author{
Laurent Châtel and Thibaut Clément
}

This media file cannot be displayed. Please refer to the online document http:// journals.openedition.org/angles/1119

\section{Transcript:}

Welcome to this Angles issue on "The Cultures and Politics of Leisure in the British Isles and the United States."

How do you pin down leisure? You could think of water, for instance. Leisure could be watching the flow of water and indulge in daydreaming, or it could be about swimming, or sailing: that's fun all right. But there's more to leisure than meets the eye: there's class, there's identity, and there's politics. This issue's central assumption is that leisure raises central issues about culture and politics.

Indeed, the divide between leisure and "productive work"-to which it is traditionally opposed-has never been an impassable wall, but rather a porous boundary involving dynamics of control, negotiation, and hybridization. Far from a mere holiday or retreat from society, leisure represents a specific domain of activities in which core social and cultural values and structures are expressed, reified, transmitted, learned, manipulated, and resisted. Cultural historian Johan Huizinga found play to be "productive of a culture," while sociologist Erving Goffman viewed games as "worldbuilding activities." Psychoanalyst Donald Winnicott referred to play as the locus of the "cultural experience," and anthropologist Clifford Geertz borrowed Jeremy Bentham's concept of "deep play" to convey the high stakes that certain leisure activities can hold for their participants. Leisure and play have throughout history intersected with issues of cultural identity, gender norms, political engagement, or labor regimes both in Britain and the United States.

4 We have divided the articles into two groups:

A. "Leisure, Public Engagement and Shared Communities"

B. "The Work/Leisure Frontier: Tourism, Gambling, Gardening, and Surfing the Web as Objects of Control, Discipline and Legislation" 
Group A brings together five contributions. First, we take a plunge in the wonders of leisure and sports with Olaf Stieglitz's 'Swimming and Modern Female Bodies in the United States, 1900s-1930s'. Stieglitz analyzes the role of the illustrated press in promoting swimming as a physical activity for women and the development of a new swimming style, the crawl. Then, in 'We Are the One: Subcultural Politics and Leisure in Early San Francisco Punk', Michael Stewart Foley and Marijn Rombouts examine the role of "fun" as a form of political engagement in the punk subculture of late 1970s San Francisco: punks carved out an ever-expanding space for participation, promoting an alternative lifestyle that escaped the grip of commercial capitalism while reserving ample time for leisure and political engagement. In her 'Making the art of fun freely accessible', Mathilde Bertrand argues that the British community arts movement in the 1970 s and 1980s took on a decidedly collective dimension with imaginative activities channelling energies in order to trigger collective action on issues affecting people's lives. Equally collective is Simon Roberts's endeavour as demonstrated by Karine Chambefort in her 'Outdoor Leisure Activities'. She shows how traditional leisure such as hiking, paragliding, angling, bathing and sea-bathing are processed into pictures of English life not just because these activities themselves are quintessentially English (which they are not, in fact) but because of the way Roberts has premised his work on a public consultation taking into account the public's suggestions and feedback as he was making his We English. Contemporary British leisure is further widened by Sarah Pickard with her 'Serious Leisure' as she examines the legitimacy of considering young people's political activism as leisure per se. With a theoretical framework of serious leisure, she establishes that involvement in collective action does count as leisure and revokes the assumption that leisure is all hedonism.

Group B starts with an article discussing the moral cost of tourism. In 'Early tourism in New Mexico: A Primitivist Pastime or a Tool of Integration?', Suzanne Berthier-Foglar explores how Natives were quick to capitalize on tourists' perceptions of Native culture as a rejuvenating antidote to modernity: she belies, at least in part, traditional takes on the necessarily exploitative and colonial dimension of cultural tourism. At about the same time in Britain, betting became the focus of attention of the British government in an effort to curb illegal practices: in 'Controversy and Compromise over Popular Gambling in Interwar Britain', Emmanuel Roudaut explores the limits of political legislation on an age-old practice which served very lucrative commercial ventures. In 'Meaningful Plots', Arnaud Page provides an historiographical review of the study of allotment gardening in Britain at the turn of the twentieth century: he shows how "allotment gardening" as a form of leisure had always served a political, social and cultural purpose in the light of governmental policies to frame and channel allotment gardening, considered an ideal leisure for the poor to balance off their weight of labour. In 'Stages of American Capitalism, Labor Regimes and Leisure Forms: From Slavery to Digital Capitalism', Olivier Frayssé highlights the rise of prosumerism namely when users' leisure time activities are used as a source of profit for corporations, effectively making users co- producers of goods and services. While corporations have long sought to profit from their workers' leisure time and provided them with activities especially compatible with their professional life, American corporations have harnessed new technologies and media platforms that not only blur the distinction between work and leisure by accommodating them both, but now allow them to rely on the work of amateurs. 
7 We hope you enjoy this issue.

\section{ABSTRACTS}

This video introduces the thematic contributions on 'The Cultures and Politics of Leisure in the British Isles and the United States'.

La vidéo présente les contributions thématiques sur "Les cultures et politiques de loisirs dans les Îles britanniques et les États-Unis".

\section{INDEX}

Keywords: video, literature, history, language, leisure, politics, United Kingdom, Ireland, GreatBritain, United States

Mots-clés: vidéo, langue, littérature, histoire, politique, Royaume-Uni, Irlande, GrandeBretagne, États-Unis, loisirs

\section{AUTHORS}

\section{LAURENT CHÂTEL}

Co-Guest editor of Issue 5. Professor at the Université Lille 3.

\section{THIBAUT CLÉMENT}

Co-Guest editor of Issue 5. Associate Professor at the Université Paris Sorbonne. 